
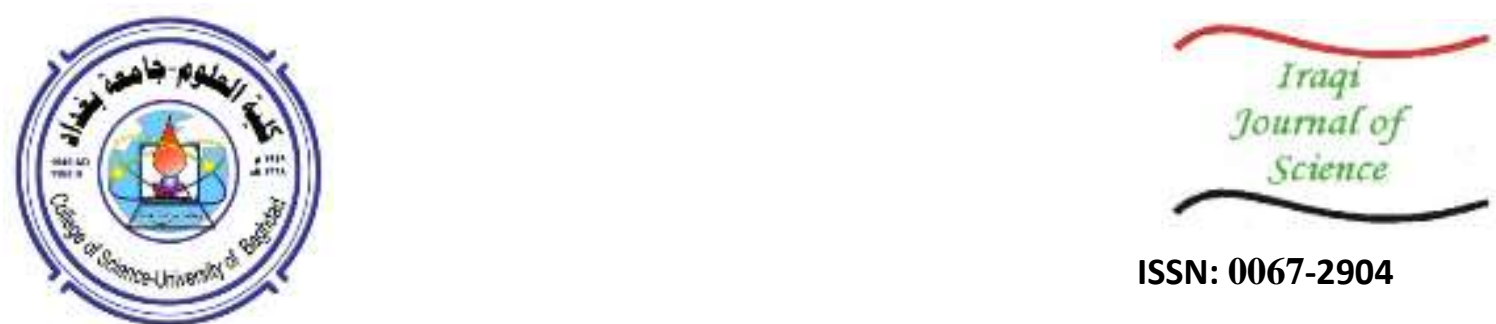

ISSN: 0067-2904

\title{
A study of the Effect of Urbanization on Annual Evaporation Rates in Baghdad City Using Remote Sensing
}

\author{
Ali K. Mohammed Ali*1 ${ }^{1}$, Fouad K. Mashee Al Ramahi ${ }^{2}$ \\ ${ }^{1}$ Department of Physics, College of Science, University of Baghdad, Baghdad, Iraq \\ ${ }^{2}$ Remote Sensing Unit, College of Science, University of Baghdad, Baghdad, Iraq
}

Received: 18/8/2019 Accepted: 19/11/2019

\begin{abstract}
The city of Baghdad has recently witnessed an increase in urban land due to the recent economic growth, which negatively affected the environment of the study area through the retraction of the agricultural lands surrounding the city. Therefore, we studied the relationship between increasing urban expansion and changes in the local climate of Baghdad for the period from 2008 to 2018. The information derived from the satellites utilized in this search showed the changes in ground cover during the study period, while the evaporation rate data source from the European Center for Forecasting (ECMWF) confirmed the effects of urban expansion on evaporation rates. Increasing urbanization increased evaporation rates and decreased vegetation degradation (NDVI). Satellite data from Landsat (TM) and Landsat (OLI) for 2008, 2013, and 2018 were processed and analyzed using the ArcGIS program. The visuals were classified into urban land, sparse plant, dense plant, water, bare soil, and wet soil. The results of the classification showed that the percentage of urban land was $26.5 \%, 28.3 \%$, and $30.9 \%$ for the years of 2008, 2013, and 2018, respectively. On the other hand, the MNDWI value for the studied years was $2.0 \%$, $1.9 \%$ and $3.6 \%$. The highest rate of urbanization was in 2018 which was accompanied by highest evaporation rates. The study proved that there was a significant correlation between increasing urbanization and evaporation rate in the study area. These results indicate that the poor planning of land use leads to negative effects on the local climate.
\end{abstract}

Keywords: MNDWI, land cover, NDI, Evaporation, remote sensing, March.

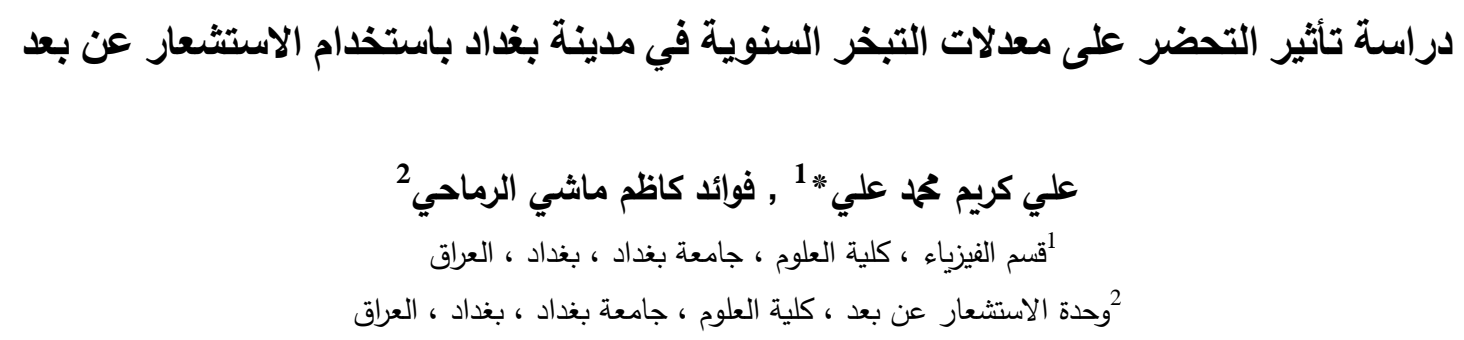

$$
\begin{aligned}
& \text { الخلاصة } \\
& \text { شهدت مدينة بغداد مؤخرًا زيادة في الأراضي الحضرية بسبب النمو الاقتصادي الأخير ، مما أثر سلبًا }
\end{aligned}
$$

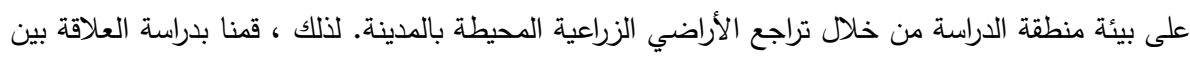

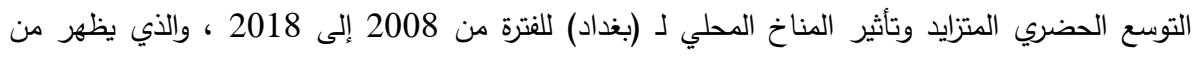

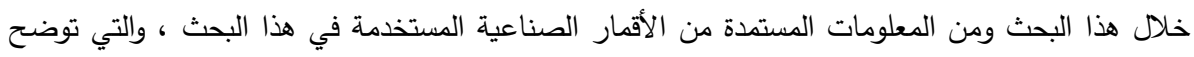

*Email: g66gg166@gmail.com 


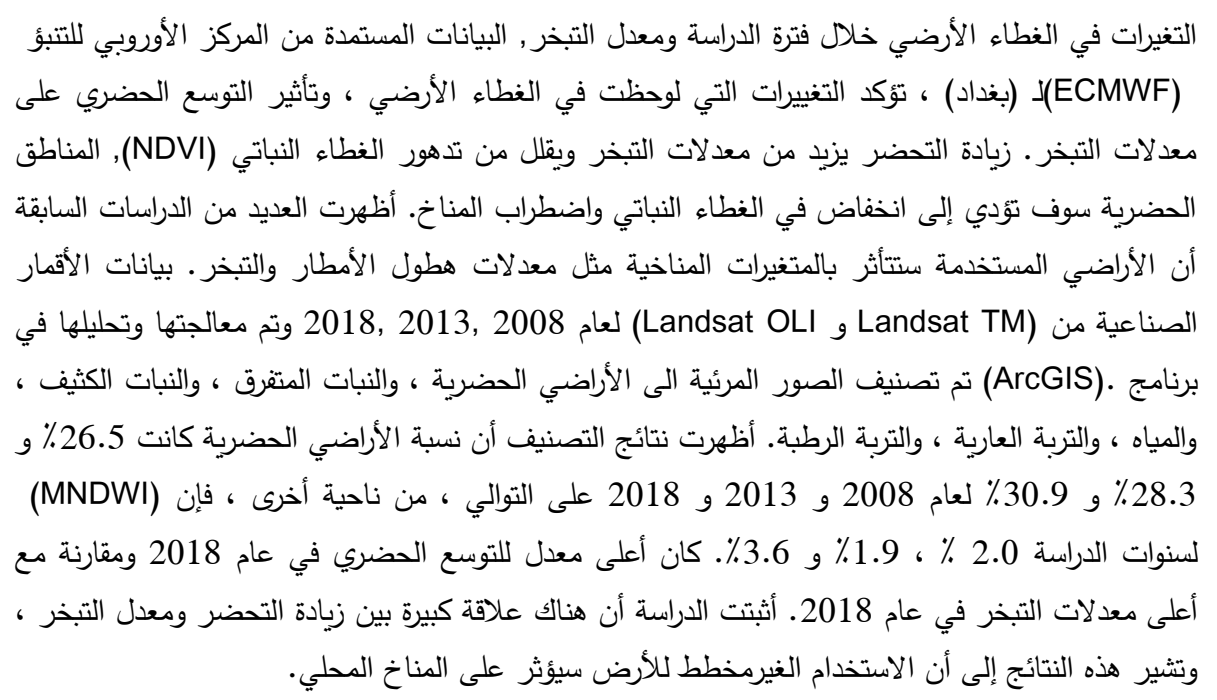

\section{Introduction}

Climate change is a long-term global problem that occurs as a result of complex interactions of environmental, economic, political, social and technological conditions and has significant impacts on the international and regional levels, including the Arabic region. Climate change and its associated unprecedented acceleration of heat energy change decrease in rainfall, and change in spatial distribution represent clear effects that govern human compatibility with the environment. This change is different from one region to another in the world, often with negative effects on water resources. Especially, the arid and semi-arid regions characterized by low rainfall and random distribution are expected to be significantly affected by the climate change proposed to occur during this century, which will lead to major changes in the hydrological cycle and evaporation [1]. Urbanization is one of the most common areas of land use in changing the hydrology of a region. Urbanization is defined as the increase in population structures at the expense of agricultural land, resulting in loss of vegetation [2]. Human activities are responsible for modern climate change, since human is not a neutral factor. But various activities of humans have accelerated the occurrence of indicators of climate change indirectly by changing the characteristics of the Earth and modifying the water cycle and certain characteristics of the atmosphere. These include deforestation, burning, overgrazing, urbanization at the expense of agricultural and forestry lands, agricultural expansion at the expense of forests and pastures, draining swamps, land settlement, dam construction, river diversion, fossil and nuclear fuels in power generation, industry, transport, and others. All of these activities lead to many changes, including changes in the water cycle. They also release large quantities of gases and dust in the atmosphere, which can also cause changes in the radiation and thermal balance and thus, climate change [3]. The benefit of satellite remote sensing depends on the integration of high-resolution satellite data to characterize the complex urban land cover tissue that contributes to local climate responses [4].

\section{The boundaries of the study area}

The region of the present research is located within the city of Baghdad, which is Iraq's capital and a major managerial center. Baghdad is situated on both sides of the Tigris River in the central portion of Iraq, with geographical coordinates of latitude $33.452^{\circ} \mathrm{N}$ to $33.184^{\circ} \mathrm{N}$ and longitude $44.189^{\circ} \mathrm{E}$ to $44.576^{\circ} \mathrm{E}$. Baghdad is Iraq's biggest and densely inhabited city. The peak of the capital's north is $48 \mathrm{~m}$ and that of the capita's south is $23 \mathrm{~m}$ higher than the water level. Therefore, there are no real natural boundaries that restrict the aerial reach of the city [5]. Baghdad's population is almost 7,500,140, covering a neighborhood of about $205.1 \mathrm{~km} 2$. The Tigris crosses the town and splits it into 2 sections: Karkh (west) and Rusafa (east). The eastern region borders Diyala watercourse that connects the Tigris River to Baghdad's southwest, as shown in Figure- 1. The 24-km Military Canal abandons the Tigris within the northern portion of the city and finishes within the southern portion of the Diyala River [6]. 


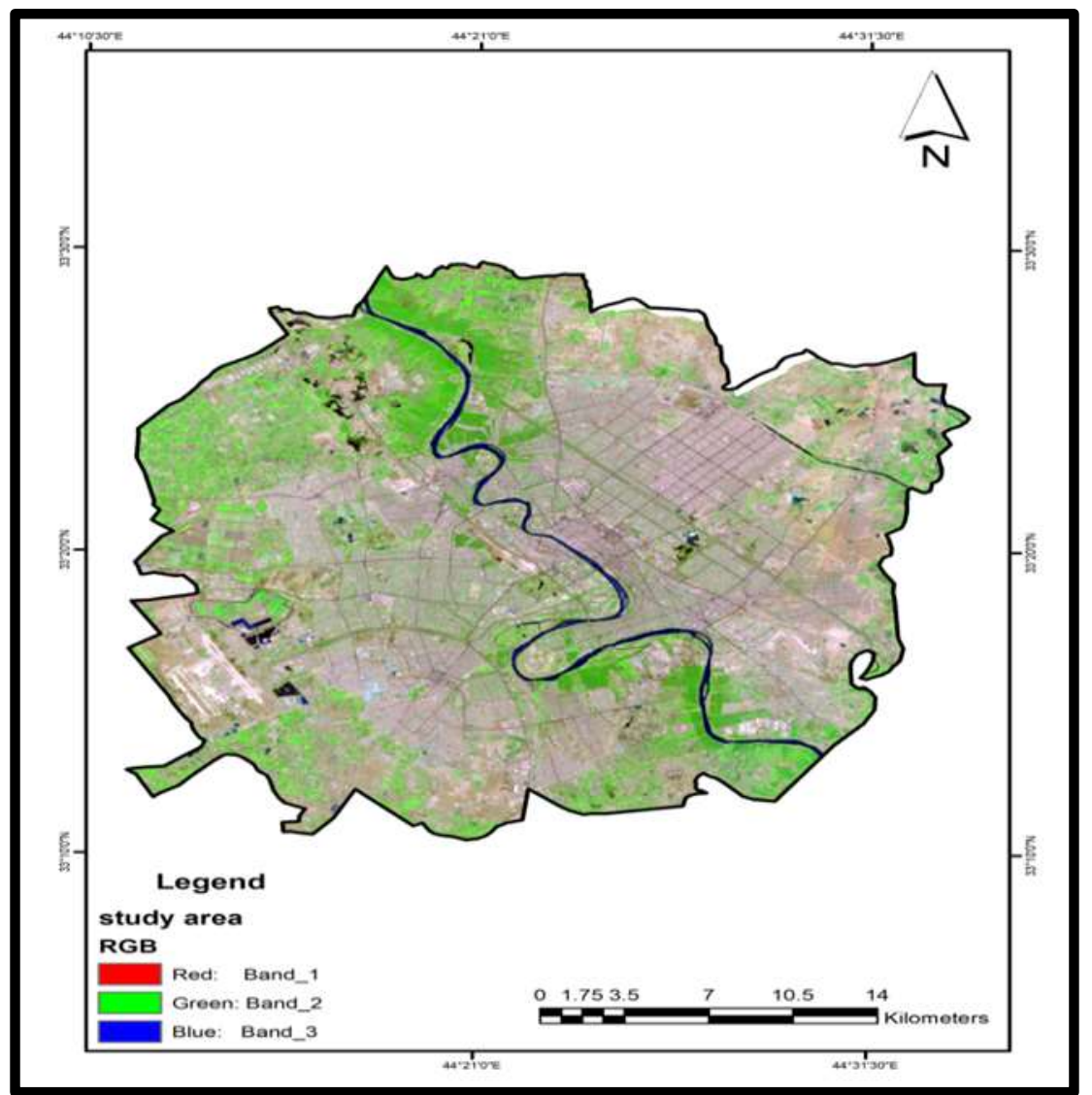

Figure 1-The study urban area of Baghdad City, Capital of Iraq.

\section{Materials and Methods}

\subsection{Climate}

Data were obtained from the European Center for Medium-Range Weather Forecasts for a period of ten years from 2008 to 2018. Evidently, the annual evaporation rate significantly increased and the annual rainfall relatively increased. The average temperature was $24,30^{\circ} \mathrm{C}$, which decreased to ${ }^{\circ} \mathrm{C} 23$, $21{ }^{\circ} \mathrm{C}$ in 2013 and increased to $23.30^{\circ} \mathrm{C}$ in 2018 . The average relative humidity was $72.95 \%$ in 2008 , which decreased to $71.50 \%$ in 2013, and then increased to $80.182 \%$ in 2018 . Dry climate with limited seasonal rains usually occur in summer time. The rainy season runs from November to April, according to Coupon Geiger Classification.

\subsection{Evaporation}

Evaporation is one of the most important natural processes related to the climate, during which water is transformed from liquid to gas and spreads in the form of water vapor, in which the air can carry water atoms.

The evaporation condition occurs when the air is in a lower level than saturation (i.e., able to carry evaporated water molecules). If the air is absorbed, the water vapor molecules in the atmosphere condense and return to the Earth's surface. There are several factors influencing the amount of evaporation, including solar radiation, which is a major source of energy used in evaporation [7]. Evaporation occurs strongly during the daytime, where $80-90 \%$ of the evaporation rate occurs between $6 \mathrm{am}$ and $6 \mathrm{pm}$, with the largest percentage of evaporation in the summer. Another factor is the deficit in water vapor pressure proportional to the evaporation rate. The third factor is water temperature, which affects the pressure of the water vapor in the air layer touching the surface of the water. Analysis of climatic data revealed that there were spatial and temporal differences between the evaporation rates of the stations of the study area. This is due to several factors, including temperature and wind speed, with a direct relationship with the latter, because the wind carries water vapor to distant places, reducing water vapor pressure and evaporation rates [8]. The analysis also showed that the highest evaporation rate was in 2018 while the lowest was in 2008, as shown in Table- 1 and Figure- 2. 
Table 1-Annual evaporation values during the study period.

\begin{tabular}{|c|c|c|c|c|c|c|c|}
\hline Year & \multicolumn{7}{|c|}{ Average } \\
\hline $\mathbf{2 0 0 8}$ & 0.103513 & 0.105751 & 0.107989 & $\ldots \ldots \ldots \ldots \ldots$ & 0.109719 & 0.107597 & 0.105474 \\
\hline $\mathbf{2 0 1 3}$ & 0.168512 & 0.172777 & 0.177045 & $\ldots \ldots \ldots \ldots \ldots$ & 0.220541 & 0.217056 & 0.213572 \\
\hline $\mathbf{2 0 1 8}$ & 0.269469 & 0.2278561 & 0.287653 & $\ldots \ldots \ldots \ldots \ldots$ & 0.250855 & 0.252713 & 0.255068 \\
\hline
\end{tabular}

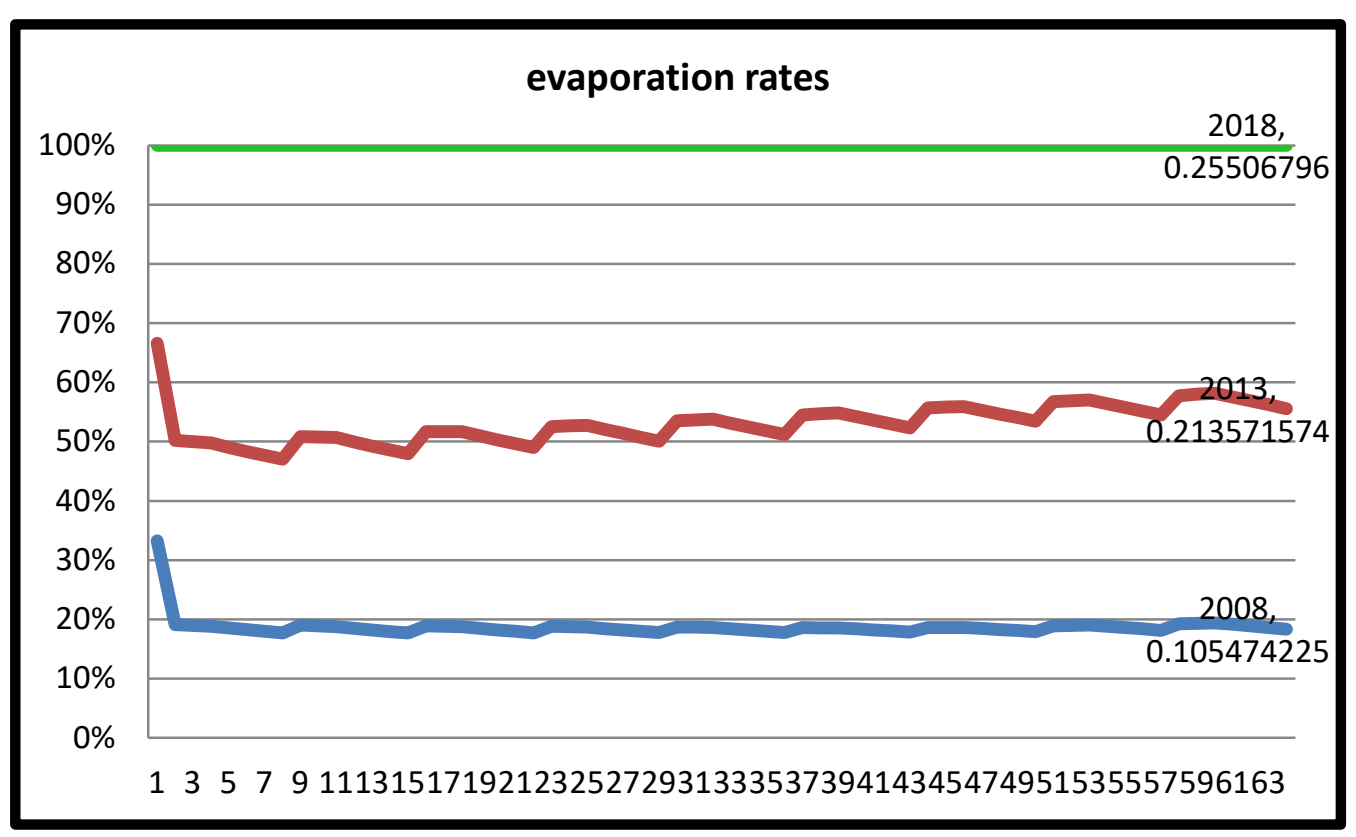

Figure 2-Differences in evaporation rates in the years 2008, 2013, and 2018.

\subsection{The Urban Expansion for Cities}

Cities are expanding internally at the expense of green areas and externally at the expense of the surrounding agricultural areas. This problem is affecting all countries in the world, especially with rapid population growth as in Iraq's population which increases by $3 \%$. This increase is a claim for the growth of urban development before agricultural areas due to the surrounding cities. Population growth in general is an increase in birth rate compared to death in the case of natural population growth or migration. This requires a new expansion in the construction of residential complexes. For better planning for such population increase, it is very important to regulate the buildings to take into account the requirements of the future. The design of cities takes into account a number of variables such as the local climate and the partial climate. This is the basis for the design of installations which should consider the direction of solar radiation to decrease or increase the solar receiver, as well as the prevailing wind direction, which affect climate predictions [9].

\subsection{Data Source and Processing}

Pre-processing of satellite images before extraction of ground cover is necessary to remove noise and increase the likelihood of interpretation of image data. This is especially true when a time series of images are used or when an area is included by many images, because it is essential to make these images spatially and spectral compatible. ArcGIS was implemented in this study for collection, input, processing, analysis, presentation and output of data. The Landsat satellite data series was adopted and images were downloaded from the website (https://earthexplorer.usgs.gov). These visualizations revealed the change of the earth cover and called in the program. The following processes were performed for each of the images in isolation: cutting space visuals, integrating spatial images, and 
processing spatial images. Bands $(7,5,3)$ and $(7,4,2)$ for Landsat 8 and Landsat 5, respectively, were used to detect changes in land cover [10], as in Table-2.

Table 2-Bands used in the production of classification maps.

\begin{tabular}{|c|c|c|}
\hline $\begin{array}{c}\text { Landsat 5 } \\
\text { (TM sensor) }\end{array}$ & $\begin{array}{c}\text { Wavelength } \\
(\boldsymbol{\mu m})\end{array}$ & $\begin{array}{c}\text { Resolution } \\
(\mathbf{m})\end{array}$ \\
\hline Band 7 & $2.08-2.35$ & 30 \\
\hline Band 4 & $0.76-0.90$ & 30 \\
\hline Band 2 & $0.52-0.60$ & 30 \\
\hline $\begin{array}{c}\text { Landsat 8 } \\
\text { (OLI and } \\
\text { sensor TIRS) }\end{array}$ & $\begin{array}{c}\text { Wavelength } \\
(\boldsymbol{\mu m})\end{array}$ & $\begin{array}{c}\text { Resolution } \\
(\mathbf{m})\end{array}$ \\
\hline Band 7 & $2.11-2.29$ & 30 \\
\hline Band 5 & $0.77-0.90$ & 30 \\
\hline Band 3 & $0.53-0.59$ & 30 \\
\hline
\end{tabular}

Three maps were completed for the study dates of 22-03-2008, 31-03-2013, and (15-03-2018 to determine the layers of land cover.

\subsection{Classification of land cover}

In the broad sense, image classification is defined as the extraction of different categories or topics (e.g., land use categories, plant types) from remotely sensed satellite data. The wave classification of land cover and land use was implemented in the ArcGIS program where the ground cover information with the same spectral signature was extracted and then merged into one class of three images. These images were extracted from remote sensing images into six categories of land cover (Built-up land, clay land, bare land, dense plants, dispersed plants, and water bodies) as in Table- 3 and Figure- 3 . Thus, we produced land cover maps and classified the years of study. Each color category represents a map of the land cover. For example, the red is for the yellow and muddy land, the brown balloon is for the dense vegetation, the green balloon is for the sparse vegetation, and the pale green balloon and the blue are for water areas.

Table 3-Land cover/land use classification for 2008, 2013, and 2018.

\begin{tabular}{|c|c|c|c|c|c|c|}
\hline year & $\begin{array}{c}\text { water } \\
\text { bodies }\end{array}$ & $\begin{array}{c}\text { dense } \\
\text { plants }\end{array}$ & $\begin{array}{c}\text { dispersed } \\
\text { plants }\end{array}$ & $\begin{array}{c}\text { built up and } \\
\text { urban area }\end{array}$ & $\begin{array}{c}\text { Clay and } \\
\text { wetland }\end{array}$ & $\begin{array}{c}\text { barren } \\
\text { land }\end{array}$ \\
\hline $\mathbf{2 0 0 8}$ & 37020600 & 183109500 & 2037349800 & 1383170400 & 1004786100 & 575801100 \\
\hline $\mathbf{2 0 1 3}$ & 53103600 & 79884900 & 1992497400 & 1475344800 & 889128000 & 731406600 \\
\hline $\mathbf{2 0 1 8}$ & 65469600 & 73785600 & 2245040100 & 1612386000 & 554715900 & 669840300 \\
\hline
\end{tabular}

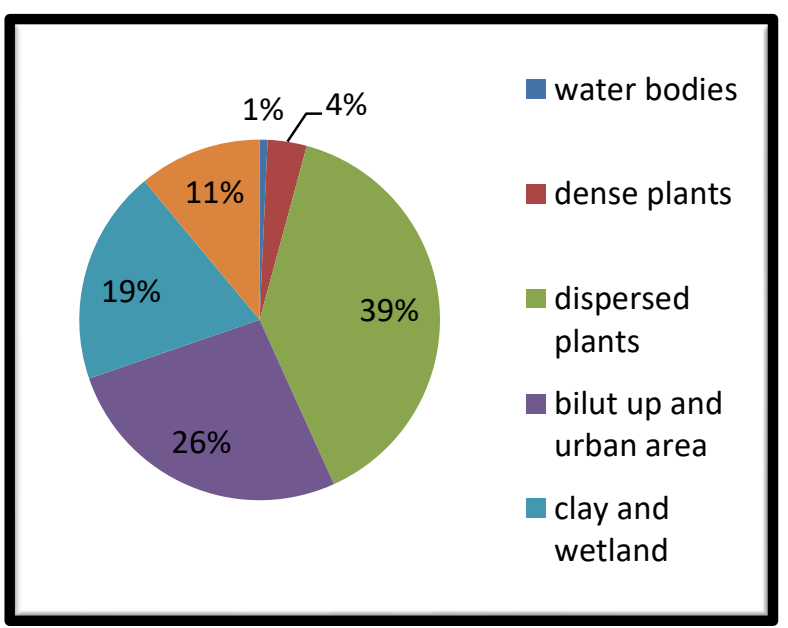

Figure 3-Changes in land cover in the years of 2018, 2013, and 2008. 


\subsection{Water index (MNDWI)}

The water index was used to monitor the water condition in the study area. In general, water is reflected only in visible light, because in the near infrared spectrum the water has no reflection, and it is very different among other surfaces. Thus, water surfaces are obviously described in pictures collected in the near infrared spectrum as dark regions (small pixel values). Equation 1 was used depending on the ranges of the water index of the relevant Landsat data that was calculated from TM and ETM + during 2018, 2013, and 2008, respectively. Figure- 4 represents the state of the study area's water bodies. It demonstrates a general water rise in 2013 and 2018 and a decline in 2008. There are several reasons for the decrease in most surface water in the study region, such as the decrease in water flow from the upstream nations and the absence of precipitation.

The following equation was used to extract water index value [11].

$$
\text { MNDWI }=\frac{\text { GREEN }-M I R}{\text { GREEN }+M I R}
$$

where MIR is a middle infrared band and Green is a green band.

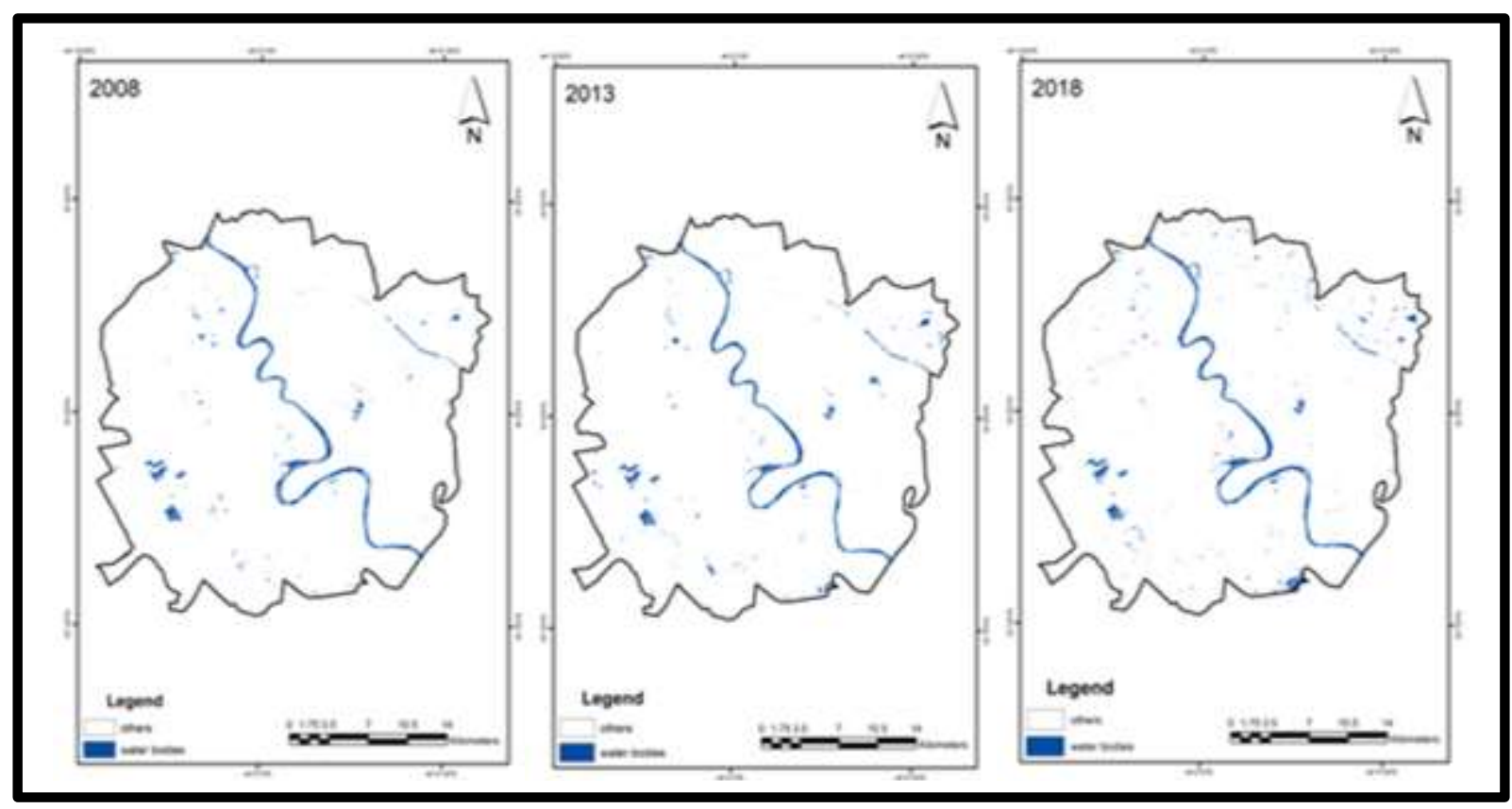

Figure 4-Water index values for the years of 2008, 2013, and 2018.

\subsection{Normalized Difference Built-up Index (NDI)}

Another guide presented in this search is NDI for urban or overcrowded urbanization in Baghdad. It represents the ratio between the differences in spectral reflectance. The NDI is used to extract the built-in features. It has a range of indicators from -1 to 1 where the negative value represents water bodies and the positive value represents construction areas. The plants will be low. The construction index of the Landsat-related data was calculated from TM and ETM + through 2018, 2013, and 2008 . Figure- 5 represents the state of urban areas in the study area. There is a general increase during the study period, where equation 2 was used to extract urban areas [12].

where

$$
\mathrm{NDI}=\frac{\text { Blue }-\mathrm{NIR}}{\text { Blue }+\mathrm{NIR}}
$$

Blue is a blue band,

NIR is a near infrared band. 


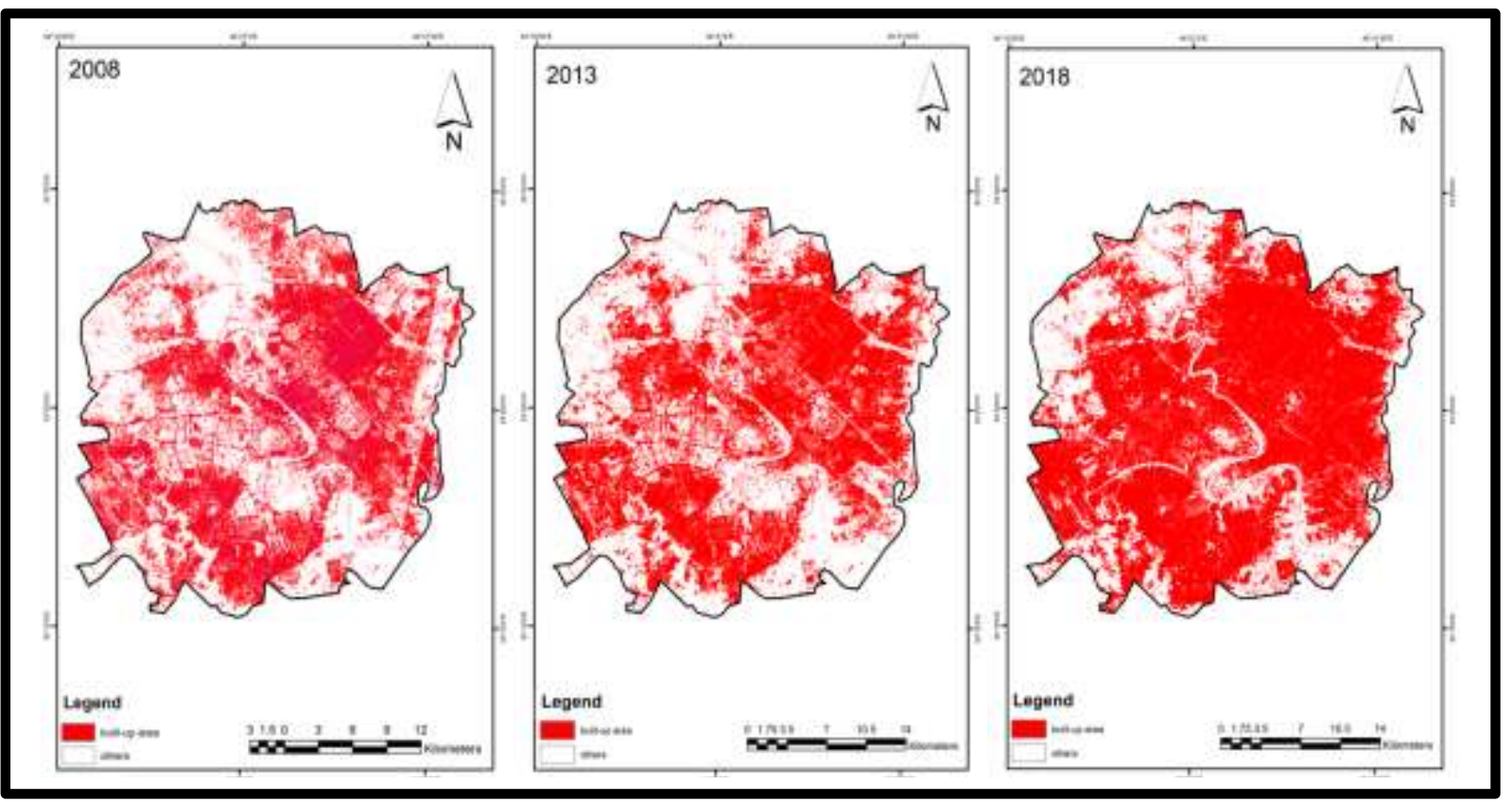

Figure 5-The urban index for the years of 2008, 2013 and 2018.

\section{Results}

The results obtained from the classification of land cover were composed of images classified into six categories, which include; urban areas, water, sparse plant, dense vegetation, and wetlands. Urban expansion during the period of 10 years from 2008 to 2018 was increased. The highest evaporation rate for the years 2008-2013 was recorded in 2018. The highest evaporation rate was in 2018 (maximum $0.28 \mathrm{~mm}$ ) and the highest value for urbanization was also in $2018\left(16123800 \mathrm{~m}^{2}\right)$. This indicates a soft relationship between increased urbanization and evaporation as shown in Fig 6 and Table- 4. One of the results obtained from the MNDWI also shows that the high water percentage NH (3.6\%) was in 2018. This indicates that the presence of water in this year was more than other years; the rate of precipitation in 2018 was $0.27 \mathrm{~mm}$, which is higher in comparison with other years.

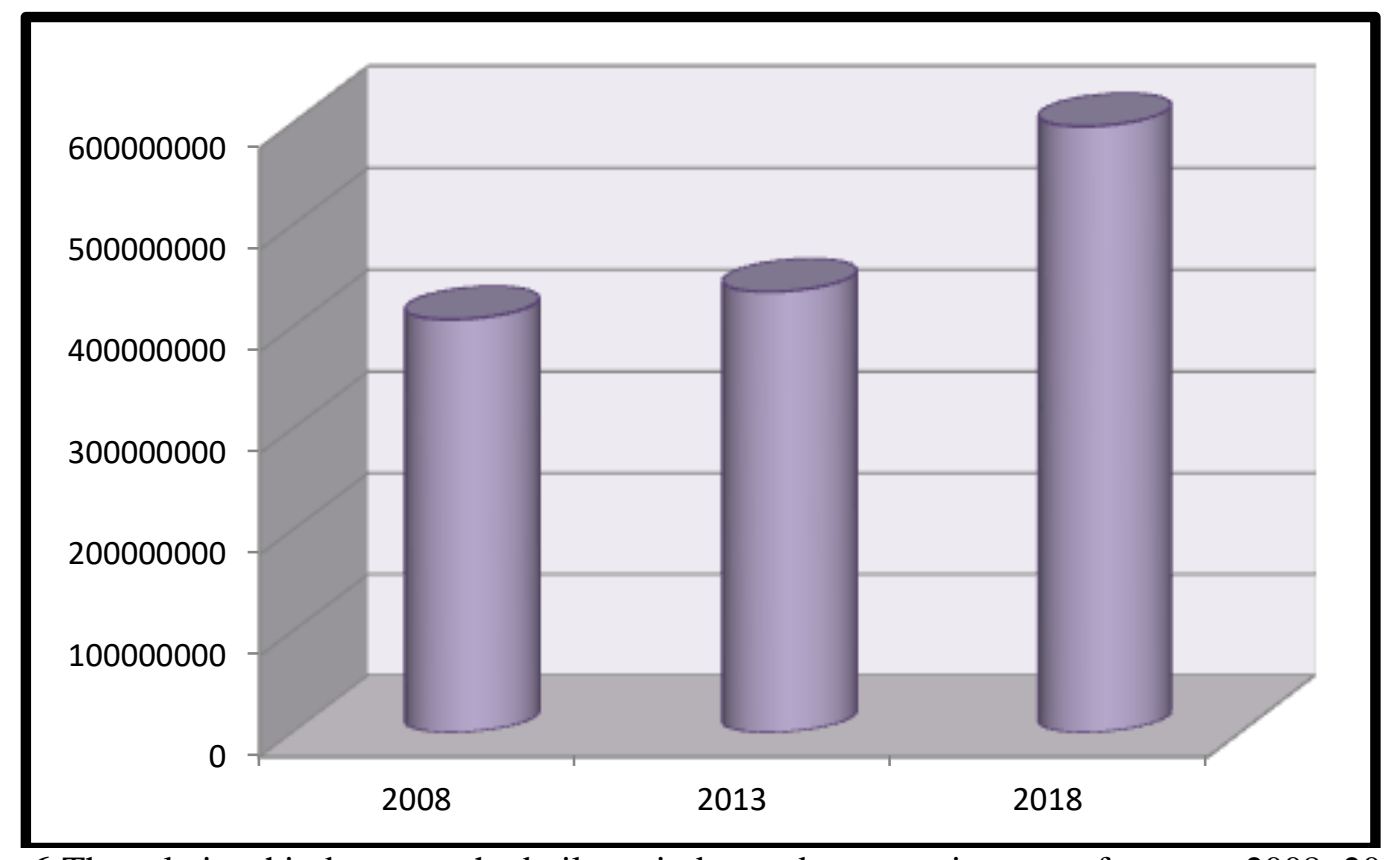

Figure 6-The relationship between the built-up index and evaporation rates for years 2008, 2013 and 2018. 
Table 4-The values of the built-up index and evaporation rates for years 2008, 2013 and 2018.

\begin{tabular}{|c|c|c|}
\hline Year & Evaporation & Built-up Index \\
\hline $\mathbf{2 0 0 8}$ & 0.107176 & 407523600 \\
\hline $\mathbf{2 0 1 3}$ & 0.199155 & 434700900 \\
\hline $\mathbf{2 0 1 8}$ & 0.273496 & 597017700 \\
\hline
\end{tabular}

\section{Conclusions}

Our results demonstrate how distinct types of urban design in a climate change can boost or reduce the vapor pressure associated with water and temperature throughout the neighborhood. As discussed in the Baghdad City case, urban design highlights the potential function of adverse urban climate control through urban design that improves evaporation. As in past studies, vegetation plays a major role in reducing the temperature and decreasing the urban heat island. Water evaporation from irrigated planting fields increases the exchange of latent heat and decreases the surrounding environment temperature. Refrigeration effectiveness improves in shaded regions, reducing water consumption by more than $50 \%$ of the dry warm environment. These findings have significant consequences for future urban planning and design, as potential strategies for climate adaptation and in reaction to potential warming. The findings show that land cover and water use are naturally interwoven across the neighborhood as they appear to influence regional material energy equilibrium. Therefore, urban land use design and water management should be completely dissolved into city design, that can facilitate future population development while minimizing adverse effects on human health and natural resources.

\section{References}

1. Budairi, A. L. 2018. Impact of climate change on evaporation trends and possible future scenarios in Iraq. (p. 411). PhD thesis, Baghdad University College of Education Ibn Rushd, Department of Geography.

2. Dow, C. L. 2000. Trends in evaporation and Bowen ratio on urbanizing watersheds in eastern United States. Journal of Water Resources Research, 36(7): 9.

3. Jubouri, O. A. 2014. Indicators of climate change and their impact on the variability of relative humidity in southern Iraq. (p. 138). Master Thesis, Baghdad University College of Education Ibn Rushd, Department of Geography.

4. OWEN, T. W. 1998. An assessment of satellite remotely-sensed land cover parameters in. Journal of Remote Sensing, 19(9): 19.

5. Bukheet, Y. C. 2016. Land Cover Change Detection of Baghdad City Using Multi-Spectral Remote Sensing Imagery. Iraqi Journal of Science, Special Issue(Part A): 195-214.

6. Ali, S. M. 2014. Analyzing the Terrorist Operations in Baghdad Using the RS and GIS Techniques. International Journal of Science and Research (IJSR), 3(11): 6.

7. Mertah Naji Abd, Gheidaa Sabeeh Al-Hassany, 2019. Estimation of Average of Global Solar Radiation Depending on Sunshine Duration Hours for Iraqi Metrological Stations, Iraqi Journal of Science, 60(12).

8. Hadi, S. K. 2019. The impact of climate change on relative humidity trends in the central region is Iraq. (p. 351). Master Thesis, Baghdad University College of Education Ibn Rushd, Department of Geography.

9. Alhashimi, A. K. 2017. Determination of Temperature Difference between Urban and Rural areas for Baghdad City. (p. 82). Master Thesis, Mustansiriya University College of Science, Department of Atmospheric Sciences.

10. Fouad K. Mashee and Gheidaa S.Hadi. 2017. study the wet region in anbar province by use remote sensing (RS) and geographic information system (GIS) Techniques, Iraqi Journal of Science, $\mathbf{5 8}$ (3A): 1333-1344.

11. Kwang, C. 2017. Comparing of Landsat 8 and Sentinel 2A using Water Extraction Indexes over Volta River. Journal of Geography and Geology, 10(1): 7.

12. Vigneshwaran, S. 2018. Etraction of built-up area using high resolution sentinel-2a and google satellite imagery. International Conference on Geomatics and Geospatial Technology. 3(5): 5. 